AL.2.1987-211 L- -

3. 2. II moly 3. 1 (3)

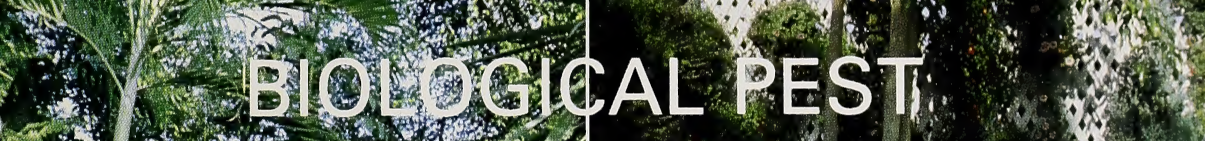
T. WIS GEMENT

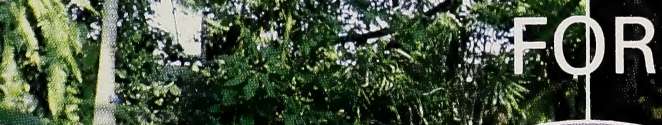

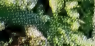
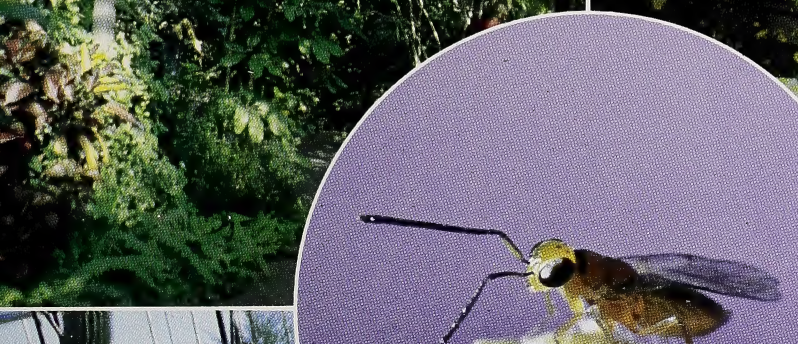

W.
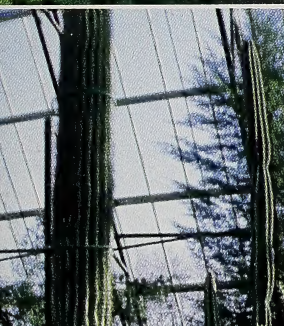

Xistion int

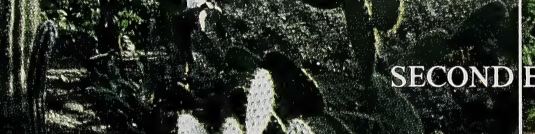

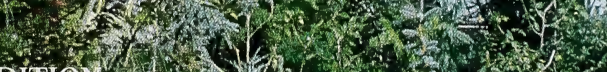

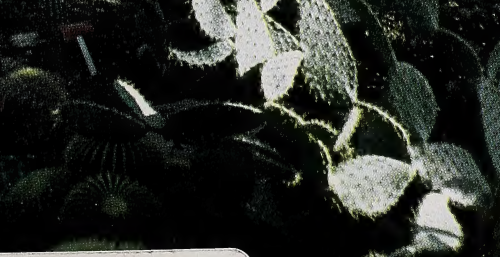

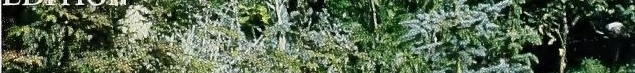
1.

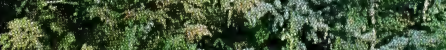

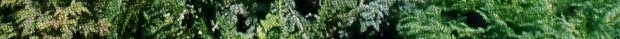

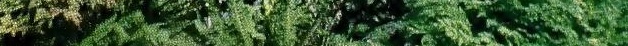

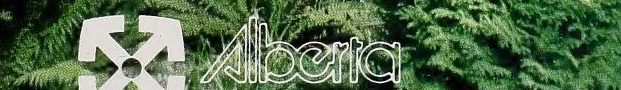
4. 2 NVIRONMENTAL CENTRE 
Front centre photograph Leptomastix dactylopii, parasite of citrus mealybug. Jack Scott. Surrounding photographs: Muttart Conservatory, Edmonton, Alberta. Marilyn Steiner. 


\section{BIOLOGICAL PEST MANAGEMENT FOR INTERIOR PLANTSCAPES}

\section{SECOND EDITION}

Marilyn Y. Steiner

Entomology Section

Alberta Environmental Centre

VEGREVILLE, Alberta

TOB 4LO
Don P. Elliott

Applied Bio-Nomics Ltd.

P.O. Box 2637

SIDNEY, British Columbia

V8L 4 C1

\section{ALBERTA ENVIRONMENTAL CENTRE}

VEGREVILLE, AB TOB 4LO

AECV87-E1

March 1987 
This report may be cited as:

Steiner, M.Y. and D.P. Elliott. Biological pest management for interior plantscapes. 2nd ed. Vegreville, AB. Alberta Environmental Centre. 32p. 1987. AECV87-E1

ISBN: 0-919975-12-7

NOTE

Copies of this publication may be obtained at a charge of $\$ 2.50$ each (Canadian Funds).

Cheques or money orders are to be made payable to "The Provincial Treasurer" and mailed with your order to:

\author{
Alberta Public Affairs Bureau \\ Publication Services \\ 11510 Kingsway Avenue \\ EDMONTON, AB \\ Canada T5G 2 Y 5
}




\section{ACKNOWLEDGEMENTS}

Appreciation is extended to the staff at the Muttart Conservatory, Edmonton, Alberta, and the Crystal Gardens, Victoria, British Columbia, for their cooperation and use of their facilities for developing biological control recommendations; also to Linda Gilkeson, Applied Bio-Nomics, Sidney, British Columbia, for slides and current information on Aphidoletes aphidimyza. 


\section{TABLE OF CONTENTS}

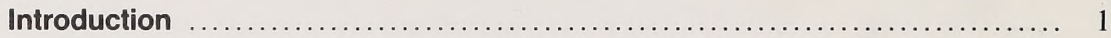

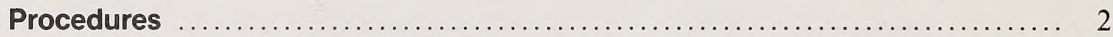

Recommended Pesticides $\ldots \ldots \ldots \ldots \ldots \ldots \ldots \ldots \ldots \ldots \ldots \ldots \ldots \ldots \ldots \ldots \ldots \ldots \ldots \ldots \ldots, \quad 3$

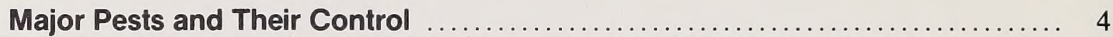

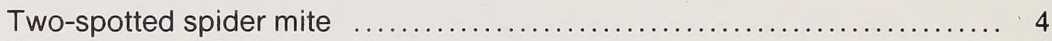

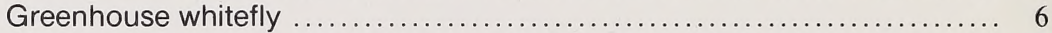

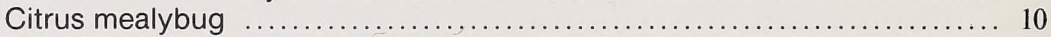

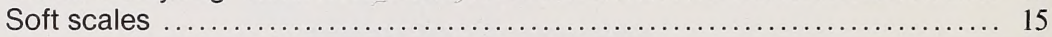

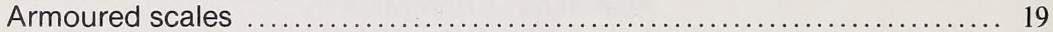

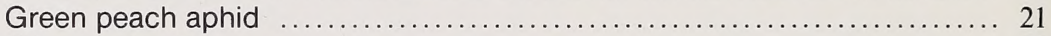

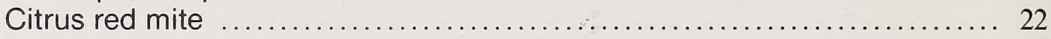

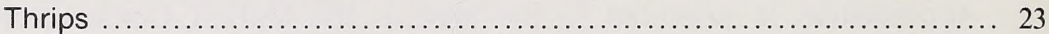

TABLE 1 Minor Pest Problems and Their Control ..................... 26

TABLE 2 Summary of Primary Predators and Parasites of Major Plant Pests .. 27

TABLE 3 Reported Toxicity of Common Greenhouse Pesticides to Various

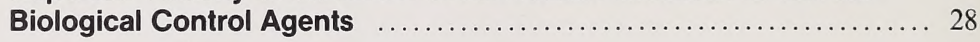

TABLE 4 Suppliers of Biological Control Agents $\ldots \ldots \ldots \ldots \ldots \ldots \ldots \ldots \ldots \ldots$

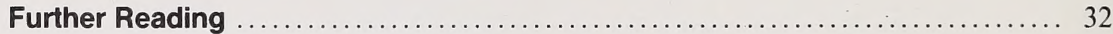




\section{INTRODUCTION}

The term 'biological control' refers to the use of living organisms to control other, less desirable, living organisms. Biological control of plant pests is a very active and growing area of research, although it is not a new concept. There are many published reports on the use of biological control agents or organisms in commercial crops such as orchards, forests, field crops and greenhouse vegetables. This booklet is intended to fill an information gap in the rapidly growing area of the interior plantscape. This now extends from public conservatories to extensive plantings in homes, hotels, shopping malls, office buildings, restaurants, schools, hospitals and other environmentally sensitive areas where it is difficult to use toxic pest control products. The information in this booklet has largely been obtained from the authors' experience in using biological control organisms in interior environments in Alberta and British Columbia. Brief notes have been made on a number of minor pests that may cause problems in the absence of routine chemical treatments. Much can be said for prevention rather than cure; sanitation and quarantine procedures should be maintained and strictly applied.

Interest in biological control has expanded with recognition of the limitations of pesticides and with consumer awareness of environmental concerns. Pesticides, once the panacea for all pest problems, have lost favor as a result of insecticide resistance, high cost, phytotoxicity and potential human health hazards. The title of this booklet, however, is not intended to imply that biological control has replaced pesticides. The emphasis in this booklet is on the combined or integrated use of biological control agents with cultural and chemical control measures. The objective of this technique is not pest elimination necessarily, but pest management, whereby pests are maintained below outbreak potential and below a visible plant damage threshold, at acceptable costs in terms of time and money. Biological control is not a system that looks after itself. It requires time, commitment and an understanding of the principles involved. Properly carried out, however, the rewards are in greatly reduced pesticide use and inventory, no chemical damage to plants, far less likelihood of resistance build-up, and fewer public concerns. 


\section{PROCEDURES}

1. Establish a reliable source of biological control agents. American supply houses will channel shipments through Canadian suppliers to avoid individual import permit requirements and to reduce costs. Because the number of commercial producers is limited (see page 30 ), and shipments must be routed by air or courier service for the shortest possible delivery time, a route should be established well in advance.

2. Prepare a plan of action.

(a) Identify all present and potential pest problems. Seek expert advice to correctly identify pests.

(b) Establish a monitoring schedule. Check leaves from several plants at various heights and locations using a x10 power magnifying hand lens. Monitor problem plants at least once a week and others at least once a month.

(c) Establish a schedule for predator/parasite introductions. Remember that if they are too successful they run out of food and die and must be reintroduced.

3. Prepare a control program budget. Initial cost will be higher than spraying until the system is balanced. Allow $\$ 3 / \mathrm{m}^{2} /$ year initially.

4. Acquire pesticides which can be safely integrated with biological control agents. (See Recommended Pesticides, page 3 and also Table 3, pages 28 and 29 for further information on insecticides and fungicides.)

5. Keep co-workers informed. 'Accidental's sprayings of unauthorized pesticides can cause havoc.

6. Act promptly to rectify imbalances. This week's build-up can be next week's outbreak.

7. Keep written records of successes and failures of parasite/predator introductions, and of pesticide applications and dosages.

8. Have patience. There are no instant results with biological control agents because of the lag time between introduction and multiplication. Start with low pest populations and be prepared to step in and augment with spot chemical applications. 


\section{RECOMMENDED PESTICIDES}

The pesticides listed here can be safely used with biological control organisms if used as directed.

Insecticidal Soap - This material is effective against most of the common pests. Coverage should be thorough. Although it may be toxic to a variable degree to exposed stages of biological control organisms, its lack of insecticidal properties once dry makes it a useful material where such organisms are absent or where localized treatments are necessary.

Fenbutatin-oxide (Vendex ${ }^{\circledR}$, Torque ${ }^{\circledR}$ ) - A miticide used to control several species of plant-feeding mites, including two-spotted and citrus red mites. It is relatively harmless to predatory mites, so can safely be used where phytophagous mite control is required. It does not affect other biological control agents.

Pirimicarb (Pirimor ${ }^{\circledR}$ ) - Because this material is fairly toxic its use should be restricted to spot treatment at low rates for aphid control. It has limited activity against other pests and is not always very effective against some strains of green peach aphid, particularly on flower buds. It does not appear to seriously affect the more commonly used biological control agents, although it has a shortpersistence activity against adult Encarsia and some strains of predatory mites. Diazinon-Use of diazinon is restricted to soil drenches for soil-dwelling stages of thrips and soil pests such as sowbugs and millipedes. Canadian strains of Phytoseiulus persimilis are selected for resistance to diazinon.

Petroleum Oils - Certain highly refined horticultural summer oils are effective against a wide range of pests and can be used as spot treatments at $1 \%$ dilution without seriously affecting predators and parasites. Care should be taken to check for phytotoxicity on plants to which it is to be applied. Some plants, particularly non-woody material, are quite sensitive to oils.

Bacillus thuringiensis $\left(\right.$ Dipel $^{\circledR}$, Thuricide ${ }^{\circledR}$ ) - A bacterial insecticide used mainly against caterpillars. Harmless to mammals, birds, fish and biological control agents. The active components are bacterial spores and crystals of a toxin produced by the bacterium. When eaten by the caterpillar, these crystals cause paralysis and disturb the gut. The spores germinate, allowing the bacteria to escape, multiply and eventually invade the blood. Death of the caterpillar may take several days, but feeding ceases shortly after ingestion of the spray deposit. Good coverage is essential.

\section{NEW DEVELOPMENTS}

Vertalec $^{\circledR}$ and Mycotal ${ }^{\circledR}$ are commercial formulations of the insect-pathogenic fungus Verticillium lecanii which infect aphids and whitefly, respectively. Their shelf life is short and they must be kept in cool storage. A requirement for high humidity restricts practical usage. Commercially available in Europe, but not in Canada or the United States.

Nemas ${ }^{\circledR}$ and Neocide ${ }^{\circledR}$ are products available commercially in Canada and the United States, respectively. They consist of live insect-parasitic nematodes, Heterorhabditis heliothidis or Neoaplectana carpocapsae, in association with a bacterium. In nature they have a wide variety of insect host species. Because they require very high humidity, no sunlight, and temperatures between 16 and $32^{\circ} \mathrm{C}$, 
they are best suited for soil applications and other areas sheltered from environmental extremes. Promising results have been obtained from their use against root weevils and tree borers.

For additional information on insecticides compatible with biological control organisms, see pages 28 and 29.

\section{MAJOR PESTS AND THEIR CONTROL}

Indoor plantscapes vary considerably in plant material, environmental conditions, and microhabitats suitable for pests and their biological control agents. The recommendations given in this booklet can thus only be guidelines and the user should feel free to experiment.

\section{TWO-SPOTTED SPIDER MITE, Tetranychus urticae}

Sometimes known as the red spider mite or glasshouse spider mite, this pest is the one most frequently encountered in indoor plant environments, and most biological control programs should be centred around it. Its extensive host range, short generation time, continuous reproduction and resistance to many miticides often makes long-term control by conventional means a frustrating experience.

Damage - Mites feed by piercing plant cells with the mouthparts and sucking up the cell contents, thereby causing white speckles on the leaves. In severe infestations, browning and drying of foliage is evident and fine webbing laid by the mites can be seen on upper plant parts.

Occurrence - Two-spotted spider mites can be found on all areas of the plant, most often on middle-aged leaves unless the infestation is severe, in which case they congregate at plant tips. With some exceptions, the lower surface of the leaf is favored over the upper surface.

Appearance and life history - Adult mites are very small, oval-shaped and yellowish or greenish except for two dark spots on the back. Males are slightly smaller and slimmer than females. Young mites hatch from pearly white, circular eggs laid among the webbing on the leaf. They resemble adults except in size, and pass through three growth stages before reaching adulthood. In the fall, with decreasing daylength and cooler temperatures, adult females normally change to a light red color and hibernate in cracks and crevices. Indoors, in a constantly warm environment under supplementary lighting, only a few will enter the red hibernating phase.

Two-spotted spider mite egg laying and development is affected by temperature. At an optimum temperature of $30^{\circ} \mathrm{C}$, a female mite may lay 100 eggs and live 30 days. A new generation is produced every eight days. At $21^{\circ} \mathrm{C}$, however, this takes 14 days, and at $12^{\circ} \mathrm{C}$ (the minimum temperature suitable for development) the process takes over 40 days. Potential offspring from one mite under optimum conditions would be a staggering 13,000,000 during her lifetime. Fortunately not all survive. 
Cultural control - Mist plants frequently since spider mites dislike high humidity. Avoid high temperatures. Consider carefully if plant species particularly susceptible to spider mite infestations and/or injury are worth their keep. Remove them if not!

\section{Biological control}

Predators - A predatory mite, Phytoseiulus persimilis, is commercially available and has been used in greenhouses in Europe and Canada for several years. The adult is shiny orange in color; immature stages are a pale salmon color. Phytoseiulus may be distinguished from the 'red' two-spotted spider mite by its lack of spots, pear-shaped body, longer front legs and rapid movement when disturbed or exposed to bright light. Optimum temperatures for development are $21-27^{\circ} \mathrm{C}$. The female lays about 50 eggs which at favorable temperatures develop to adults in less than a week, allowing them to multiply twice as fast as their prey. Each can consume 5-20 eggs or mites a day. Phytoseiulus does not hibernate under greenhouse conditions. Temperatures over $30^{\circ} \mathrm{C}$ and bright light are unfavorable and are avoided. Parts of plants in bright hot sunlight will thus favor spider mites and may result in poor control in these areas. Strains of Phytoseiulus are available which tolerate high temperatures and some insecticides.

To use Phytoseiulus persimilis:

1. Avoid using residual pesticides in the month prior to introduction.

2. Introduce Phytoseiulus at first sign of spider mite damage. If there is more than an average of 1 mite/leaf, reduce spider mite populations with Vendex or insecticidal soap until no more than $10 \%$ of the leaves have mites.

3. Adjust temperatures to favor Phytoseiulus $\left(21-27^{\circ} \mathrm{C}\right)$ and keep humidity high.

4. Order Phytoseiulus at the rate of $2 / \mathrm{m}^{2}$ of planted area, $2 /$ damaged leaf or $2 /$ plant if plants are small.

5. Distribute Phytoseiulus according to susceptibility of each plant species to spider mites and to degree of infestation. Place on middle and upper foliage, preferably in early morning. Release in all infested areas. Predatory mites are mobile and will distribute themselves once they have cleaned up the area in which they have been placed. Avoid hosing down foliage. Misting is preferable and will assist in spider mite control without dislodging the predators.

6. Monitor spider mite populations at least once a week by checking new growth on all susceptible plants.

7. Reintroduce Phytoseiulus at regular monthly intervals. Initially, especially in non-atrium situations, it may be necessary to reintroduce them every two weeks until a balance has been attained, or to vary the number of predators depending on the type of planting and environmental conditions. Good control of a moderate spider mite infestation should be achieved within 4-6 weeks.

Other predatory mites are available and worth experimenting with or using to complement $P$. persimilis. Typhlodromus occidentalis is a smaller, pale covered mite which tolerates both high and low temperatures. It is more effective in 
arboreal situations and on hairy-leaved plants, and it prefers to feed on active stages of mites rather than their eggs. Amblyseius californicus is similar in appearance, effective at intermediate temperatures, and persists well at low prey densities. Phytoseiulus longipes is more tolerant of low humidities than $P$. persimilis.

Chemical control - Quarantine new plants and treat routinely with Vendex or insecticidal soap before placing among established plants. On established plants, assess whether spider mites are already being controlled adequately by Phytoseiulus before spraying. As a rough rule of thumb, plants with 1 Phytoseiulus for every 5 spider mites, or 1 leaf with Phytoseiulus for every 5 leaves on the same plant with spider mites should not require spraying unless populations are high enough to cause damage. This will be a function of plant species and environmental factors and can only be determined by experience on the part of the person monitoring. If general spider mite populations are high, reduce them with Vendex at label rates. Where infestations are localized, spot spray with either Vendex or insecticidal soap. Reintroduce predators or transfer from other locations.

\section{GREENHOUSE WHITEFLY, Trialeurodes vaporariorum}

The greenhouse whitefly has a more limited host range than the two-spotted spider mite. It is nonetheless a common pest in conservatories, though less so in other interior plantscapes because of the lack of suitable host plants. A good deal of information has been developed on biological control of this pest on cucumbers and tomatoes. In ornamental plantings this pest can breed year round. Success with biological control has been variable.

Damage - Whiteflies are sap-sucking insects in both the adult and juvenile stages. Heavily infested plants may wilt, turn yellow and grow poorly. Whiteflies also excrete a sticky material called honeydew which covers leaf surfaces and allows the growth of an unsightly black sooty mold.

Occurrence - This pest is fairly structured in its distribution on the host plant. Adults generally frequent the under surface of the top leaves of actively growing shoots. Nymphs or immature stages are to be found on younger expanded leaves. Older leaves generally bear the empty pupal 'skins' left behind by emerging adults. Whitefly populations can be expected to increase whenever growth conditions for their plant host are ideal.

Appearance and life history - Adult whiteflies, as their name suggests, are tiny, white, fly-like insects which fly when disturbed. The female lays 200-400 eggs on the underside of the leaves, setting them individually on small stalks, or on some plants, in a circle, by pivoting her abdomen around as she lays. The young nymphs resemble tiny mealybugs or aphids when first hatched, but they do not move very far before settling down to a sedentary existence. After the first molt, they lose their legs and resemble small, white, oval scales. They molt through a total of four 'instar' or growth stages to a pupa-like stage, from which the adult emerges through a $\mathrm{T}$-shaped slit cut in the outer skin.

The minimum temperature for development is $8^{\circ} \mathrm{C}$. Reported development time from egg to adult varies, but is on average 57 days at $15^{\circ} \mathrm{C}, 35$ days at $18^{\circ} \mathrm{C}, 26$ 
days at $21^{\circ} \mathrm{C}, 22$ days at $24^{\circ} \mathrm{C}, 21$ days at $27^{\circ} \mathrm{C}$ and 18 days at $30^{\circ} \mathrm{C}$. The shorter life cycle at higher temperatures is offset by a decrease in the number of eggs laid (from more than 300 at $18^{\circ} \mathrm{C}$ to less than 30 at $27^{\circ} \mathrm{C}$ ), and also a shorter adult lifespan ( 42 days at $18^{\circ} \mathrm{C}$ to 18 days at $27^{\circ} \mathrm{C}$ ), so that the optimum temperature range for population increase is $18-24^{\circ} \mathrm{C}$.

Cultural control - Select cultivars or plant species least susceptible to whitefly infestations. Misting is necessary to remove accumulations of honeydew and sooty mold on leaves. Use yellow sticky traps where practical to trap out adult whiteflies (not if Leptomastix present). These can be obtained commercially or made up from pieces of stiff card or board painted a bright yellow and coated with vaseline, vaseline/mineral oil mix, or other sticky material. A plant species highly attractive to whitefly, such as Lantana, Jerusalem cherry or Fuchsia, can be used as an indicator plant to detect infestations.

\section{Biological control}

Parasites - The chalcidoid wasp Encarsia formosa is a readily available parasite which has been in use for over 50 years. The adult wasp is about the size of a spider mite, with dark head and thorax and yellow abdomen. It makes short hopping flights, attracted by honeydew or a scent given off by the whitefly. Males are very rare. Adult females lay eggs in the third and fourth larval growth stages of the whitefly, and they also kill first, second and late fourth stages by feeding on them. The parasite grub feeds within the scale, which turns black within two weeks, providing a convenient way of assessing the success of the Encarsia introduction. Development time, adult life span and number of eggs laid is dependent on temperature. The threshold for development is $13^{\circ} \mathrm{C}$. Time from egg to adult is on the average 31 days at $18^{\circ} \mathrm{C}, 24$ days at $21^{\circ} \mathrm{C}, 15$ days at $24^{\circ} \mathrm{C}$, 12 days at $27^{\circ} \mathrm{C}$, and 10 days at $30^{\circ} \mathrm{C}$. This is a good deal faster than the whitefly at higher temperatures. Females live 15-30 days and can lay up to 400 eggs. The grubs go through three larval and one pupal stage before the adult stage. The emerging adult cuts a small exit hole in the top of the black scale, visible if held up against the light. At its optimum development temperature of $27^{\circ} \mathrm{C}$, the egg laying capacity of Encarsia is twice that of the whitefly. However, the wasp is more sensitive to cold than whitefly and below $21^{\circ} \mathrm{C}$, the whitefly lays ten times as many eggs as Encarsia. The critical temperature for good control is approximately $23^{\circ} \mathrm{C}$, however, a minimum night temperature of $15^{\circ} \mathrm{C}$ is satisfactory as long as there are enough sunny periods to raise the mean temperature over 24 hours to $23^{\circ} \mathrm{C}$. A mean temperature of $18^{\circ} \mathrm{C}$ will hold the status quo. Encarsia also does less well than whitefly at relative humidities exceeding $70 \%$, and is impeded by hairy-leaved plants and by honeydew. Encarsia has been reported as being fully reproductive only at light intensities of 7300 lux, and intensities below 4200 lux cause high mortality. This, together with the fact that they do not become active until four hours after sunrise, probably explains the poor control sometimes obtained during the winter months in plantings not receiving adequate supplementary light.

\section{To use Encarsia formosa:}

1. Avoid using residual pesticides in the month prior to introduction. 


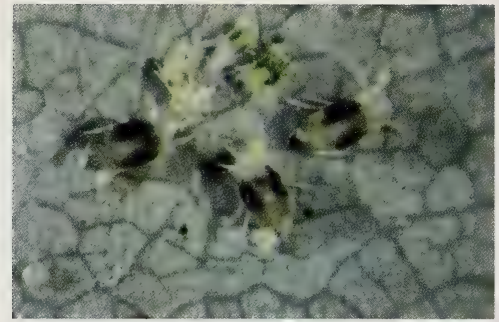

M. Herbut

Two-spotted spider mite, Tetranychus urticae

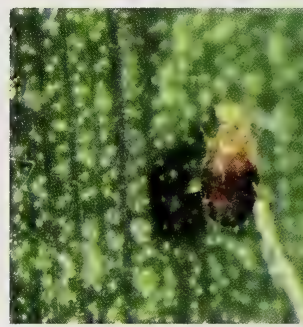

Citrus red mite, Panonychus citri

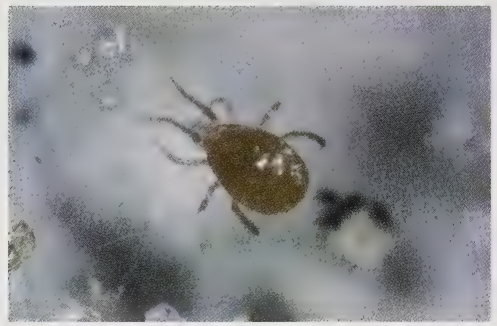

Spider mite predator, Phytoseiulus persimilis

M. Herbut

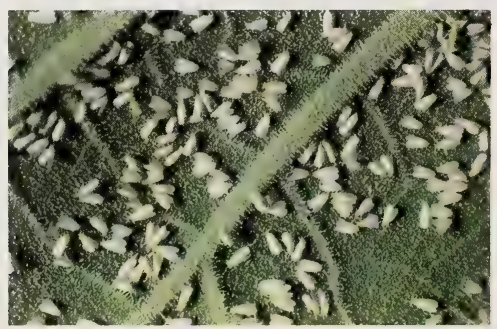

Greenhouse whitefly, Trialeurodes vaporariorum (adults)

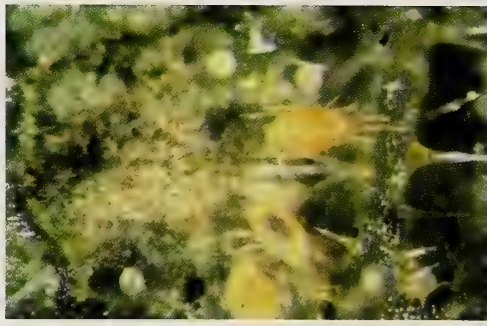

M. Herbut

Two-spotted spider mite, Tetranychus urticae, red winter phase

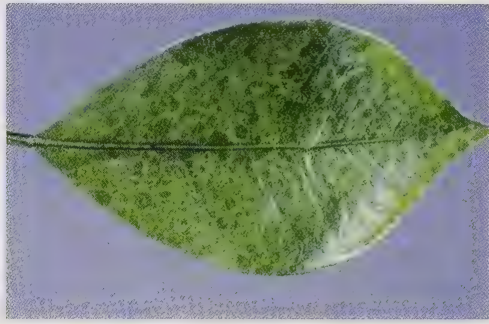

M. Herbut

Citrus red mite damage to calamondin orange leaf

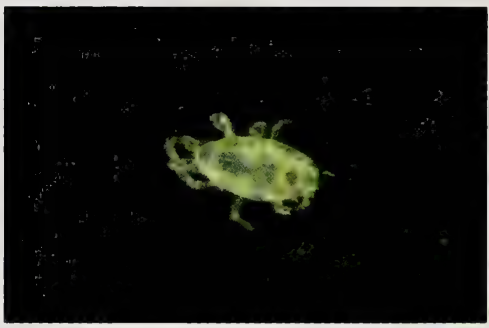

M. Herbut

Spider mite predator, Typhlodromus occidentalis

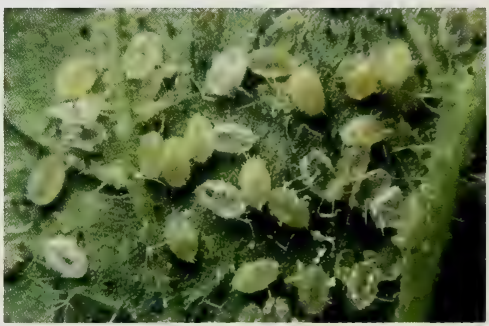

M. Herbut

Greenhouse whitefly, Trialeurodes vaporariorum (immature stages) 


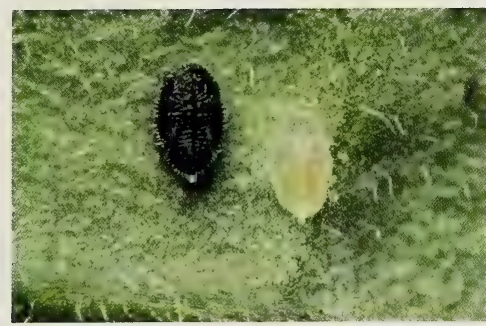

M. Herbu

Unparasitized (white) and parasitized (black) whitefly pupae

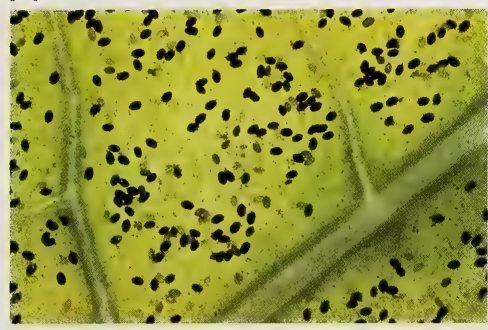

P. Dickenson

Whitefly pupae, heavily parasitized by Encarsia formosa

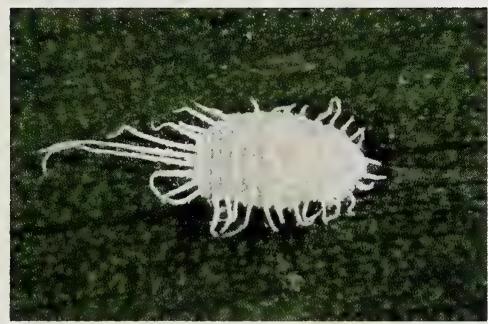

M. Herbut

Long-tailed mealybug, Pseudococcus longispinus

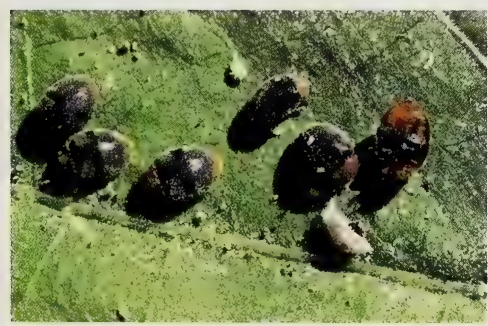

P. Dickenson

Mealybug predator, Cryptolaemus montrouzier (adult)

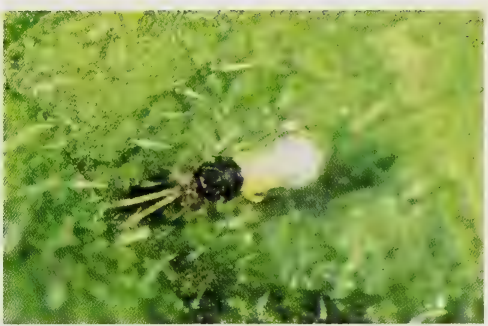

M. Herbut

Whitefly parasite, Encarsia formosa (adult)

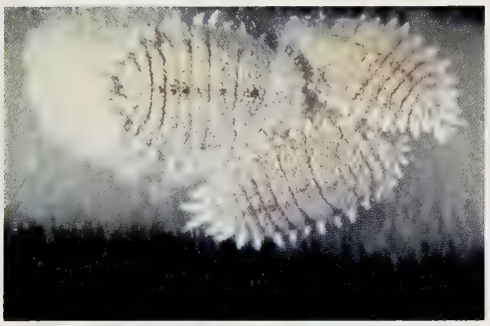

Citrus mealybug, Planococcus citri

M. Herbut

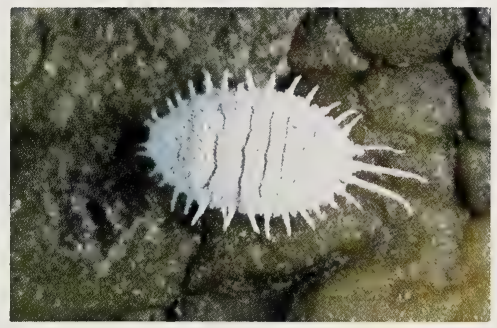

M. Herbut

Obscure mealybug, Pseudococcus obscurus

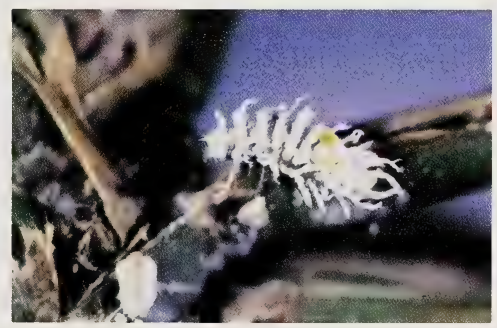

M. Herbut Mealybug predator, Cryptolaemus montrouzieri (larva) 
2. Reduce existing whitefly populations with insecticidal soap until there is on the average less that 1 adult/ upper leaf. This is a crude estimate only since populations are very dependent on environment and host.

3. Adjust temperature, humidity and light to favor Encarsia $\left(23-27^{\circ} \mathrm{C}, 50-70 \%\right.$ RH, $>7000$ lux, respectively).

4. Once populations are low or at first sign of adult whiteflies, order Encarsia at the rate of $3 / \mathrm{m}^{2}$ of planted area or $1-5 /$ plant, depending on susceptibility and size of host plants.

5. Distribute leaves or other substrates bearing black, parasitized scales in shady places on infested plants.

6. Reintroduce Encarsia every 10-14 days for a total of four introductions. This is important since adult Encarsia presence should correspond with the third and fourth instar whitefly stages to be attacked. Repeat this series if necessary, usually once or twice a year.

7. Monitor plants at least once a week by checking new growth on all susceptible plants. Black scales should be present within four weeks and good control achieved within 2-3 months. One month after the final introduction, about $80 \%$ of the whitefly scales should have turned black. If this figure is much lower, further introductions should be made. If leaves with black scales are removed, leave them among plantings for two weeks to allow emergence of Encarsia. Because of the longer life cycle of whitefly and Encarsia, control is a slower process than for spider mites. Integrate with chemical controls where necessary.

Chemical control - Quarantine, check, and treat new plants routinely with insecticidal soap before placing them among established plants. On established plants, if adult whiteflies exceed 10/leaf, spot spray the new growth of infested plants with insecticidal soap. Among large scales, the percentage of black parasitized scales should exceed 30\% after 5-6 weeks and eventually reach $75-95 \%$. Lower parasitization rates and noticeable honeydew or detrimental effects on growth may require spot spraying of scale-bearing leaves with insecticidal soap or horticultural grade petroleum oil. If whitefly populations of more than 40 adults/leaf are not treated, honeydew and sooty mold will develop.

\section{CITRUS MEALYBUG, Planococcus citri}

The citrus mealybug is the most common species found in ornamental plantings. It has an extensive host range, and thrives on soft-stemmed and succulent plants such as Codiaeum, oleander, Coleus, Fuchsia and cactus. Other mealybug species which may be encountered are the long-tailed, obscure, citrophilus, grape and ground mealybugs, which present special problems for biological control as no parasite is available. Fortunately they are far less common than the citrus mealybug.

Damage - Mealybugs are sap-sucking insects, typically distorting, stunting and yellowing foliage, but also excreting copious quantities of honeydew which attracts sooty mold and ants.

Occurrence - Citrus mealybugs are found on all parts of the plant, including the roots, but typically are clustered on stem tips and new growth. 
Appearance and life history - The citrus mealybug is a soft-bodied, oval, pink insect. The body after the first growth stage is covered by a white, waxy material, forming short filaments radiating from the margins of the body. The obscure and long-tailed mealybugs are readily distinguished by their longer tail filaments. Most mealybugs mate, the seldom-observed male being a tiny, delicate, twowinged insect which does not feed. Females lay up to 600 yellow eggs each over 8-10 days, placing them in a light cottony mass. They hatch in about 10 days and the crawlers migrate actively in search of feeding sites. Female nymphs go through three growth stages. Generation time may take a month to a year, depending upon temperature, 1-2 months being normal under greenhouse conditions. Although this mealybug prefers relatively high humidities, its observed success on cacti growing under semi-arid conditions attests to its adaptability.

Cultural control - Dislodge mealybugs by hosing down plants frequently unless biological control agents are present, in which case mist to remove honeydew accumulations. Choose plant species least susceptible to damage and infestations. Mealybugs are some of the most difficult pests to control in indoor plantings. Check new plants carefully and discard infested plants rather than risk infesting established plants.

\section{Biological control}

Predators-The Australian lady beetle Cryptolaemus montrouzieri is sporadically available for control of all species of above-ground mealybugs, and it will also feed on aphids and immature scale insects when mealybugs are in short supply. The adult beetle is $4 \mathrm{~mm}$ long, black, with orange head and 'tail'. The female lays her eggs singly among the cottony egg masses of mealybugs (longtailed mealybugs give birth to living young so beetle egg laying may be restricted). Eggs hatch in $8-9$ days at $21^{\circ} \mathrm{C}, 5-6$ days at $27^{\circ} \mathrm{C}$. The young larva sucks out the body contents of eggs and young nymphs, passing through four instars before pupating on nearby stems, leaf undersides or structural supports. These larval stages are covered with a white, waxy material and when small, closely resemble their mealybug prey (the proverbial wolf in sheep's clothing). Check carefully before pruning off or spraying apparently mealybug-infested shoots. The larval stages of Cryptolaemus extend $17-24$ days at $21^{\circ} \mathrm{C}, 12-17$ days at $27^{\circ} \mathrm{C}$, and the white pupal stages $14-20$ days at $21^{\circ} \mathrm{C}$ and $8-10$ days at $27^{\circ} \mathrm{C}$, for a total development time from egg to egg of approximately 54 days at $21^{\circ} \mathrm{C}$ and 33 days at $27^{\circ} \mathrm{C}$. Their activity threshold is $9^{\circ} \mathrm{C}$; optimum temperature for egg laying and larval development is $22-25^{\circ} \mathrm{C}$ at $70-80 \% \mathrm{RH}$. During the winter months, lower temperatures and shorter daylengths appear to inhibit their activity more than it does the mealybugs', and control may be inadequate. Cryptolaemus needs fairly high mealybug populations to satisfy its requirements, and is best used as a quick knockdown agent for heavy mealybug infestations. In that case it is not necessary to reduce mealybug numbers before introduction unless only small numbers of beetles are to be released.

\section{To use Cryptolaemus montrouzieri:}

1. Control any ants in the area since these will protect mealybugs for their honeydew. 


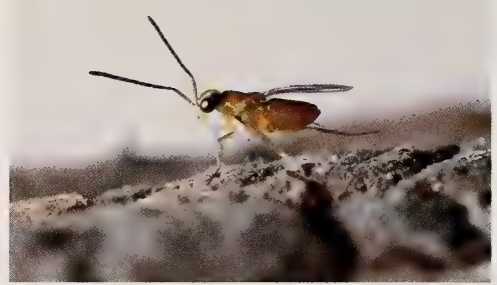

J. Scott

Citrus mealybug parasite, Leptomastix dactylopii (adult)

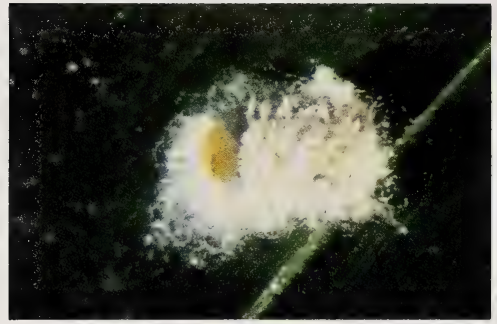

M. Herbut

Mummified citrus mealybug after emergence of Leptomastix dactylopii

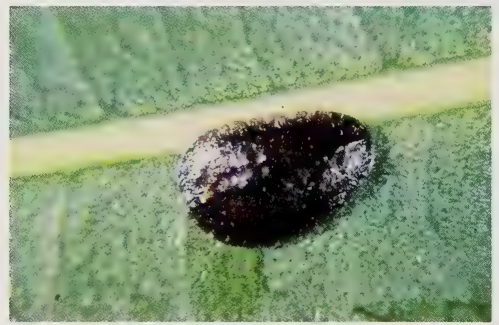

M. Herbut

Nigra scale, Parasaissetia nigra

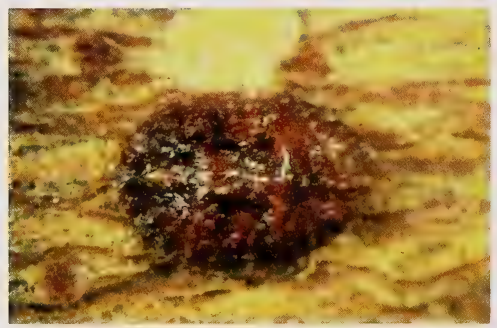

Black scale, Saissetia oleae

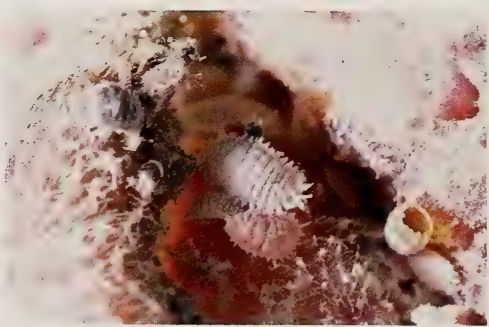

J. Scott

Citrus mealybug (centre) parasitized by Leptomastix dactylopii

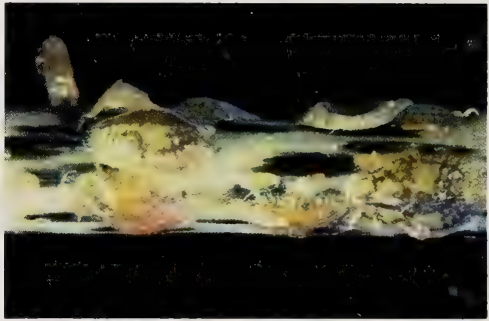

M. Herbut

Brown soft scale, Coccus hesperidum

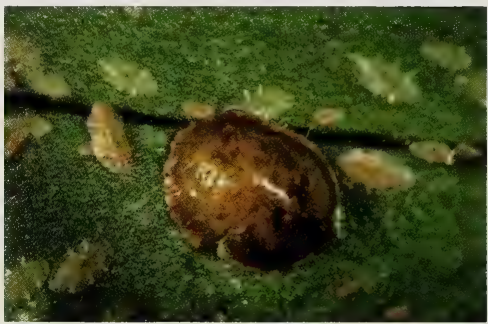

M. Herbut

Hemispherical scale, Saissetia coffeae

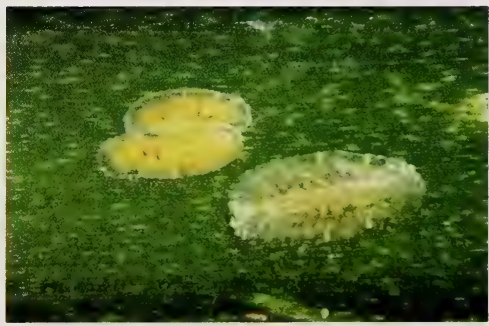

M. Herbut

Elongate soft scale, Coccus longulus 


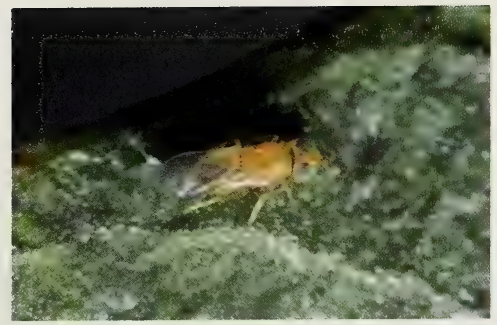

M. Herbut

Soft scale parasite, Metaphycus helvolus (adult)

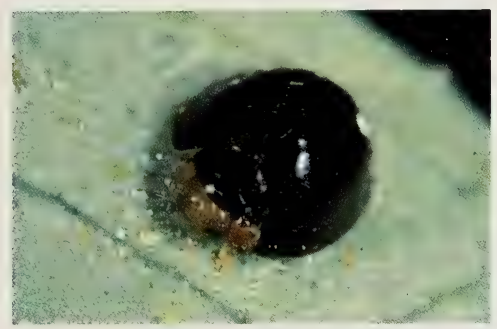

Scale predator, Chilocorus nigritus (adult)

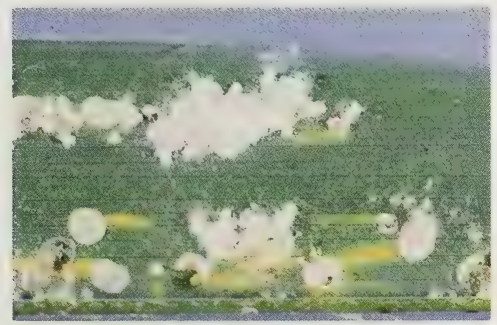

Boisduval's scale, Diaspis boisduvalii

M. Herbut

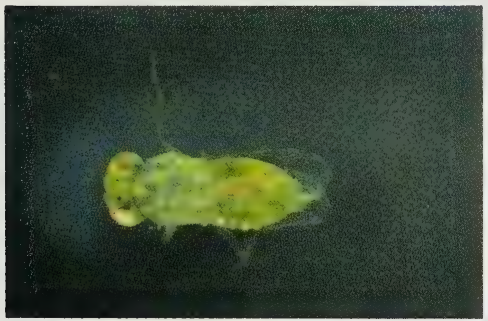

Armoured scale parasite, Aphytis melinus (adult)

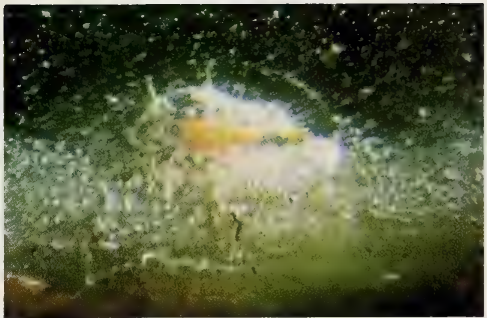

M. Herbut

Metaphycus helvolus (larva) within parasitized soft scale

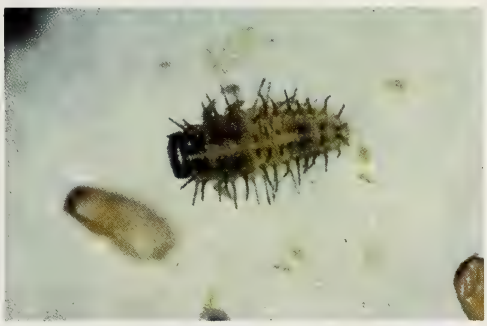

M. Herbut

Young larva of Chilocorus nigritus

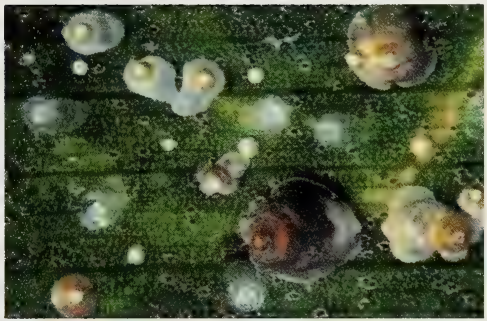

M. Herbut

False Florida red scale, Chrysomphalus bifasciculatus

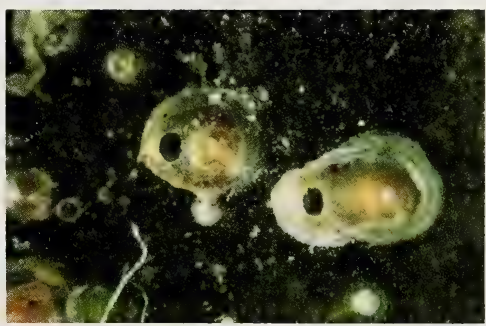

M. Herbut

Parasitized armoured scale with Aphytis exit holes 
2. Avoid using residual pesticides in the month prior to introduction.

3. Adjust the temperature to favor Cryptolaemus $\left(22-25^{\circ} \mathrm{C}\right)$ and screen vents and windows to prevent escape of beetles.

4. Order Cryptolaemus at the rate of $2 / \mathrm{m}^{2}$ of planted area or $2-5 /$ infested plant.

5. Distribute Cryptolaemus by releasing live adults at various infestation sites, preferably early morning or late evening so that they settle more readily on the plants. Avoid wearing white clothing while distributing - beetles are attracted to light colors. If possible, confine them in the release site with a little solid honey for a day before setting them free.

6. Monitor plants at least once a week by checking new growth on all susceptible plants.

Repeat releases as necessary, usually once or twice a year under favorable conditions.

The common lady beetle Hippodamia convergens will provide limited control if released in large numbers.

Parasites - The tiny wasp Leptomastix dactylopii is a valuable supplement to the control of the citrus mealybug. It does not reproduce in other mealybug species. Commercial supplies have unfortunately been sporadic in recent years. This yellowish-brown wasp has a short, hopping flight and long, tapping antennae. The female lays her eggs in the third stage nymph and adult mealybug. The developing wasp grub turns its host into a neat, legless, barrel-shaped mummy, covered with fine threads. When the adult wasp is ready to emerge, one end of the mummy unhinges to allow its exit. The adult wasp feeds on host honeydew. Leptomastix prefers a sunny, warm and humid environment, however, it has been used successfully in low humidity situations. Development time is 28 days at $24^{\circ} \mathrm{C}$ and 18 days at $27^{\circ} \mathrm{C}$. Each female lays an average of 80 eggs. Small colonies of both predator and parasite can be reared on citrus mealybugs in jars containing sprouted potatoes as food for the mealybugs. These should be kept in the dark and the predators or parasites released periodically. This will help to offset any difficulties in obtaining commercial supplies.

To use Leptomastix dactylopii:

1. Avoid using residual pesticides in the month prior to introduction.

2. Use Cryptolaemus to reduce heavy mealybug populations, or hose off dense accumulations of mealybugs with water and spray with insecticidal soap.

3. Adjust temperature to favor Leptomastix $\left(24-27^{\circ} \mathrm{C}\right)$.

4. Order Leptomastix at the rate of $2 / \mathrm{m}^{2}$ of planted area or $5 /$ infested plant.

5. Distribute Leptomastix by releasing live adults at various infestation sites.

6. Monitor plants at least once a week by checking new growth on all susceptible plants.

Repeat releases as necessary, usually once or twice a year. Good control should be achieved in 2-3 months.

Chemical Control - Quarantine, check, and treat new plants with insecticidal 
soap before placing them among established plants.

Guidelines for control are difficult to quantify for mealybugs because of their tendency to aggregate on growing tips on some plants and distribute themselves on others. In general, spot spray where female mealybugs with egg sacs are present but no Cryptolaemus or Leptomastix-parasitized individuals, particularly if growing tips are infested or the plant is sensitive to damage. The percentage of mealybugs parasitized by Leptomastix should exceed 50\%. If not, spot spray with insecticidal soap. Repeat as necessary in 7-10 days or introduce more parasites and/or predators.

\section{SOFT SCALES (Coccids)}

Several species of soft scale are included under this heading. Extensive use has been made of biological control agents for scale insect control in many areas of the world on outdoor crops, but little work has been done on indoor plantings and information on life histories of both scales and their natural regulators under these conditions is scanty or lacking. Some success has been achieved with a commercially available parasite, and the search for others is continuing.

Damage - Soft scales are related to mealybugs and inflict similar damage. They are sap suckers, typically distorting, stunting and yellowing foliage. Similarly, they excrete large quantities of honeydew, which is a useful indication of the presence of these often unnoticed pests.

Occurrence - Soft scales generally frequent the undersides of leaves and stems, but may be found on upper leaf surfaces also, depending upon the host plant and scale species. Both young and older leaves may be attacked, but scales on the stems usually select new growth.

Appearance and life history - In their outdoor habitats, scale insects generally only produce one or two generations a year. In the greenhouse or interior plantscape there may be three to six generations, often overlapping if conditions remain constant. In general, the female scale lays as many as 2000 eggs beneath her hard outer shell. After several days or weeks these hatch into mealybug-like crawlers which migrate over the plant looking for suitable feeding sites. The mortality rate of these scales is very high. The survivors, once they have settled down, go through two to four growth stages. The rare adult males are tiny, delicate, winged or wingless insects. Immature scales are paler and flatter than the adult female. Eggs are laid over several weeks and the female then dies. Most scales dislike extremes in temperature, but thrive in fairly humid warm temperature conditions and shade.

The species of soft scale listed here are the ones most commonly encountered in indoor plant environments:

1. Black scale, Saissetia oleae, prefers woody plant hosts which include weeping fig, citrus, banana and olive. Black or dark brown in color, oval and convex, it is readily recognized by a raised $\mathrm{H}$-shape on the upper surface and somewhat roughened appearance.

2. Hemispherical scale, Saissetia coffeae, is a smooth, strongly convex, shiny brown scale, roughly circular in outline. Immature stages are white and have the ' $\mathrm{H}$ ' pattern typical of the black scale. Its host plants include ferns, 


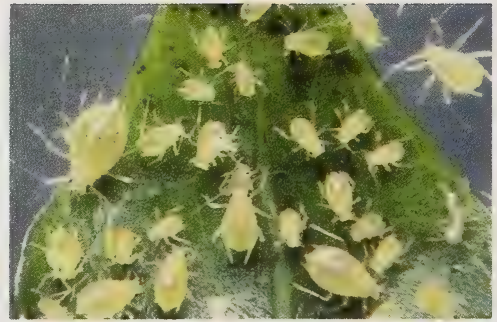

M. Herbut

Green peach aphid, Myzus persicae (nymphs)

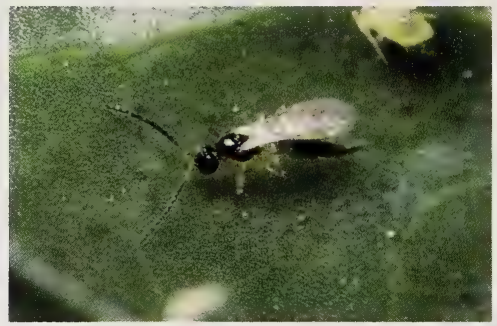

M. Herbut

A braconid wasp parasite of green peach aphid

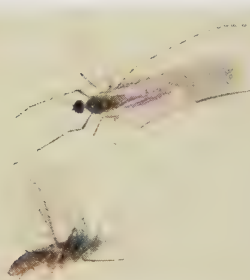

P. Langlois Aphid predator, Aphidoletes aphidimyza (adults)

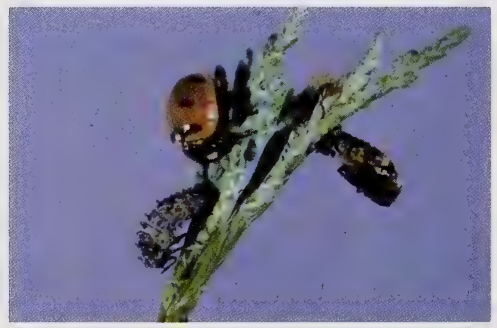

Ladybeetle (adult, larva and pupa)

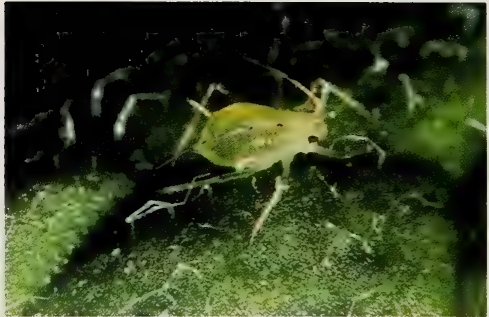

M. Herbut

Foxglove aphid, Aulacorthum solani (nymph)

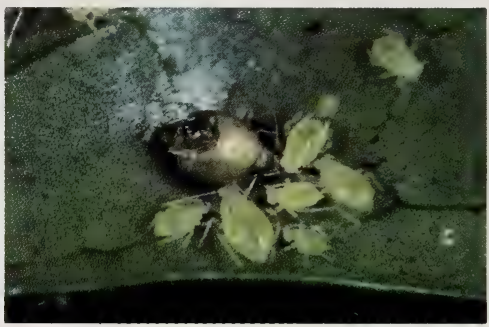

M. Herbut

Aphid mummified by a braconid wasp parasite

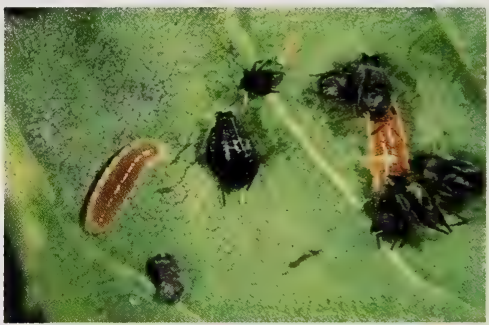

M. Herbut

Aphidoletes aphidimyza (larvae) with black aphids

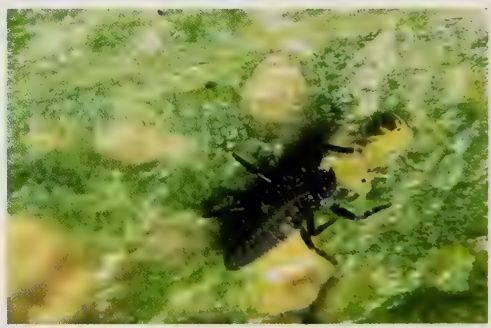

M. Herbut

Ladybeetle larva feeding on aphid 


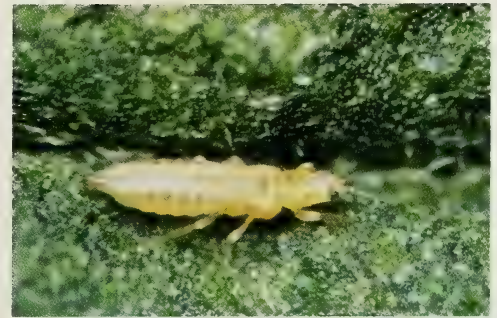

M. Herbut

Western flower thrips, Frankliniella occidentalis (adult)

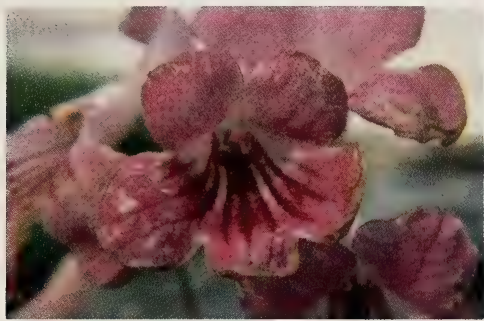

M. Steiner

Western flower thrips damage to Streptocarpus flowers

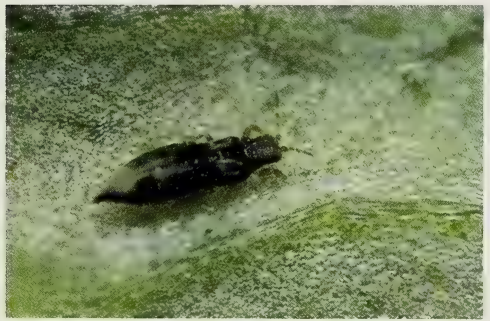

M. Herbut

Banded greenhouse thrips, Hercinothrips femoralis (adult)

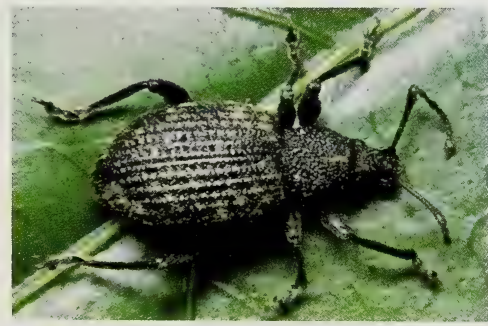

M. Herbu

Black vine weevil, Brachyrhinus sulcatus (adult)

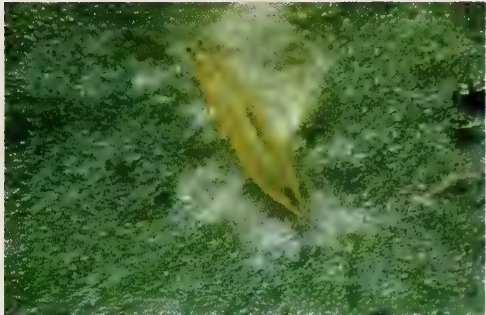

M. Herbut

Western flower thrips, Frankliniella occidentalis (larva)

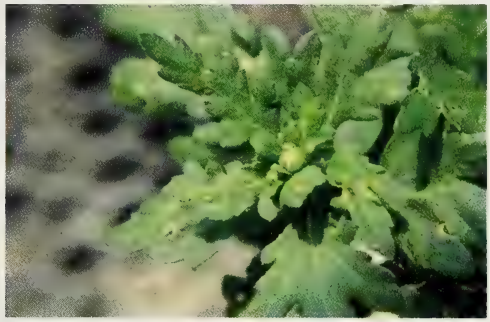

M. Steiner

Western flower thrips damage to chrysanthemum foliage

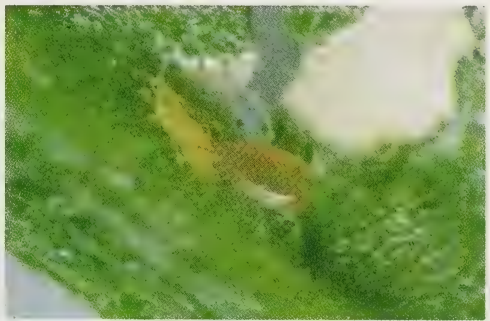

Amblyseius iroquois, a thrips predator

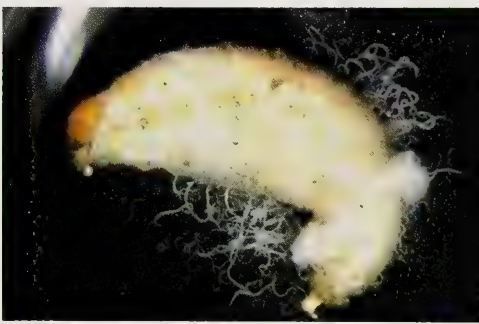

M. Herbut

Black vine weevil larva attacked by a nematode Neoaplectana carpocapsae 
Schefflera, asparagus fern and many non-woody evergreen plants.

3. Brown soft scale, Coccus hesperidum, is oval and more flattened than the black and hemispherical scales. Its color is pale brown, dirty white or greyish, mottled with dark brown on the back. The shell is pliable. Females produce living young. The elongate or long soft scale, Coccus longulus, is similar in appearance but more elongate. The brown soft scale is a copious honeydew excretor. Both species feed on a wide range of hosts, including Schefflera, weeping fig, ferns, and citrus.

4. Nigra scale, Parasaissetia nigra, can vary its size, shape and color depending on its host. On petioles or thin stems it may be slim and elongate; on leaf blades it is more oval. Its hard outer shell is shiny black or dark brown. Woody plants such as weeping fig, citrus, ivy and holly are its common hosts.

Cultural control - Prune heavily infested branches before crawlers hatch. Mist or spray with water to wash off honeydew and dislodge crawlers.

\section{Biological control}

Predators - Two small lady beetles, Chilocorus nigritus and Lindorus lophanthae, have recently become available for control of both soft and armoured scales. The adult Chilocorus is shiny black, circular, with an orange head. Eggs are laid singly or in small groups, usually in sheltered places such as under bark or under dead scales. They hatch in 3-10 days. The larva is hairy with several alternating yellowish orange and brownish black bands across its back. It matures in 2-3 weeks. The adult emerges after 5-8 days in the pupal stage. Total development time is approximately one month. Adult Lindorus is a smaller, black beetle with burnt orange head and thorax. The larva is greyish with creamy bands running lengthwise and it is hairless. Where other predators are not available, the common lady beetle Hippodamia convergens will provide limited control if released in large numbers.

Parasites - A tiny, black and yellow wasp, Metaphycus helvolus, is marketed for control of several soft scale species. Supplies are sometimes sporadic. It is particularly effective against hemispherical scale, which produces little honeydew, but less so against brown soft scale, where encapsulation of parasite eggs seems to occur quite frequently, preventing their development. In our experience it provided better control of black scale under hot, semi-arid conditions than under warm, fairly humid conditions, though this may have involved factors other than climate. The female wasp lays her eggs under the body of first and second stage scales. The grub feeds on the young scale and develops to an adult within two weeks, cutting a small exit hole which can be seen with a 10 hand lens. The adult kills older non-parasitized scales directly by feeding on them. Information on rate of development at different temperatures is lacking but it can be presumed that they like semi-tropical conditions.

To use Metaphycus helvolus:

1. Avoid using residual pesticides in the month prior to introduction.

2. Reduce heavy scale populations $2-3$ weeks prior to introductions with insecticidal soap, or horticultural grade petroleum oil.

3. Wash off accumulations of honeydew. If the leaf surface is sticky, wasps will 
spend their time cleaning themselves instead of searching and egg laying.

4. Adjust temperature to favor Metaphycus $\left(22-29^{\circ} \mathrm{C}\right)$.

5. Order Metaphycus helvolus at the rate of $5 / \mathrm{m}^{2}$ of planted area or 510 /infested plant.

6. Distribute Metaphycus by releasing adult wasps on infested plants. Repeat two or three times at 2-3 week intervals and then as necessary, usually once or twice a year under favorable conditions.

7. Monitor plants at least once a week. Small scales with parasite emergence holes should be apparent within 2-3 weeks and good control achieved within 2-3 months. Removing mature adult scales manually will assist control. Wasps can sometimes be found on the underside of the leaves at the base or along the midrib.

Chemical control - Quarantine, check, and treat new plants with insecticidal soap or petroleum oil before placing them among established plants. After 2-3 months, $50 \%$ or more of the small scales should be parasitized. If more than two adult scales or large numbers of crawlers are present per medium-sized leaf, spot spray with insecticidal soap or petroleum oil. Repeat in 7-10 days if necessary. Keep honeydew washed off.

\section{ARMOURED SCALES (Diaspids)}

Armoured scales are less commonly encountered than soft scales but can present a problem where chemical spraying is suspended under a biological control program. They often pass unnoticed initially because of their small size and non-insect-like appearance.

Damage - Armoured scales are sap-sucking insects which cause further damage by injecting toxins into the plant while feeding, resulting in yellow or brown areas around the feeding sites and eventually death of the leaf. They do not excrete honeydew.

Occurrence - Armoured scales are found on both leaves and stems where they may form thick crusts. They normally occur on the lower leaf surface, but sometimes also on both surfaces.

Appearance and life history - In general, eggs laid under the scale cover hatch into crawlers similar in appearance to mealybugs and soft scales. These wander around until they find a suitable feeding site and settle down to a sedentary existence. The skins from the first two molts are secured to the upper body by wax and become the characteristic 'nipple'. Oystershell-shaped armoured scales lay down further layers of wax while moving in an arc, hence the characteristic shape. Circular types pivot around in a circle while depositing the wax. Males are generally slimmer than females in the young stages and are winged when adult. In protected environments there may be 3-6 generations a year.

The following species are among those which may occur on ornamentals in indoor plantings. Because of the diversity of species and similarity in appearance of many of them, the service of a scale expert is best sought to confirm the identification.

1. Ivy or oleander scale, Aspidiotus nerii, is a grey or dirty white, circular and 
flattened scale with a somewhat off-centre 'nipple'. It infests many indoor plants. Males are similar to females but are more oval in shape. The greedy scale, Hemiberlesia rapax, is similar but less flattened, and prefers to aggregate on stems.

2. The false Florida red scale, Chrysomphalus bifasciculatus, is another circular scale with a central 'nipple'. The color is dark red to nearly black. It feeds on leaves and fruits of plants such as palms, rubber plant, banana and figs. Similar scales are the Florida red scale, Chrysomphalus aonidum, which is reportedly more common in greenhouses, the California red scale, Aonidiella aurantii, which is brighter reddish brown and prefers citrus, and the dictyospermum scale, Chrysomphalus dictyospermi, which is pale yellowish brown and favors palms and citrus.

3. Boisduval's scale, Diaspis boisduvalii. The female is circular, white and flattened, whereas the male is smaller and elongate with three powdery ridges along the back. Males congregate in cottony masses. This scale thrives on the leaves and bark of palms, banana, cacti and orchids. The cactus scale, Diaspis echinocacti, is similar in appearance and feeds primarily on cacti.

4. The fern scale, Pinnaspis aspidistrae, has an oystershell shape. Females are pale brown; males have white upper surfaces, parallel-sides and three longitudinal ridges. They prefer ferns, orchids and aspidistra.

5. The purple scale, Lepidosaphes beckii, is dark brown or purple and oystershell-shaped. Males are slightly smaller and narrower than females and more nearly parallel-sided. It is an important citrus pest but attacks many other plant species also.

Cultural control - Prune heavily infested branches. Mist frequently to discourage crawlers. Isolate infested plants.

\section{Biological control}

Predators - See notes under predators for soft scales, page 18.

Parasites - The tiny parasitic wasp Aphytis melinus can be obtained for control of a limited number of armoured scale species. It reportedly controls California red and oleander scales among others. It did not establish on Boisduval's scale. Aphytis melinus is a tiny yellow wasp which lays her eggs on the soft body under the outer waxy shell of third stage nymphs. Successful parasitization is indicated by an exit hole in the shell two or three weeks later.

Details for introduction have not been determined, but a procedure similar to that for the soft scale parasite Metaphycus helvolus is suggested.

Chemical control - Quarantine, check, and treat new plants with insecticidal soap or horticultural grade petroleum oil before placing them among established plants. On established plants, monitor for the presence of crawlers and spray if less than $50 \%$ of scales are parasitized and the infestation is spreading. Repeat in 7-10 days as necessary. 
Although green peach aphid is not the only aphid found on indoor plants, it is the one most frequently encountered and most difficult to control with conventional insecticides. Other species include the shiny, light green foxglove aphid, Aulacorthum solani, and the potato aphid, Macrosiphum euphorbiae, a large pink or green aphid which drops off the plant readily when disturbed.

Damage - Aphids cause direct damage by sucking sap, which results in wilting, deformation and retarded growth of the host plant. They also excrete sticky honeydew. Some species inject toxic saliva or viruses and mycoplasmas into plants, producing symptoms such as yellowing, spotting, stunting and curling of foliage.

Occurrence - Aphids are usually clustered in large colonies on new growth, at the base of buds, and on the underside of leaves.

Appearance and life history - Wingless nymphs vary in color from pale green to yellow or pink, even on the same branch. Winged adults are green with a dark irregular blotch on the back and a black head and thorax. In indoor plantings, all adult aphids are winged or wingless unfertilized females which give birth to living young. Winged forms are produced when the colony becomes overcrowded. A single female may give birth to 60-100 nymphs during her 20-30-day lifetime. The young in turn may begin to reproduce themselves 6-10 days after birth so colonies can build up very rapidly. They thrive over a wide temperature range and in moderate humidity.

Cultural control - Prune heavily infested branches and hose off aphids with water unless predators and parasites are present.

\section{Biological control}

Predators - Various lady beetles will provide some control. Some promising results have been obtained with a predaceous midge larva, Aphidoletes aphidimyza. It has been marketed in Finland and is now available in Canada and the United States. The adult midge is a small, black, delicate fly which lives on average for 10 days. After mating the female lays 100-200 tiny orange eggs on the underside of leaves close to aphid colonies and often beneath the aphids. These hatch in 2-3 days at $20^{\circ} \mathrm{C}$. The larva is orange or red and up to $3 \mathrm{~mm}$ long. Depending on temperature and food supply, it matures in 3-5 days and then drops to the ground, where it builds a cocoon $2-3 \mathrm{~cm}$ deep in the soil and pupates. At $20^{\circ} \mathrm{C}$ adults emerge in 10-14 days, a total life cycle of three weeks. The threshold for larval development is approximately $6^{\circ} \mathrm{C}$, and the optimum temperature is $23-25^{\circ} \mathrm{C}$ at $80-90 \% \mathrm{RH}$. Adult midges feed on aphid honeydew excretions. They are active only at night and at very low light conditions. The larva feeds on aphids by biting their knee joints, injecting a paralyzing toxin, and then, when the aphid has ceased struggling, biting into the thorax and sucking out the body contents. They may eat or kill 4-65 aphids each, depending on aphid density. Control will likely succeed if there is one midge egg or larva to 25 or less aphids. Diapause (hibernation) will occur in the winter months but can be prevented by leaving low-intensity lights on all night, e.g. one 60 -w bulb every 12 $\mathrm{m}$ or one $100-\mathrm{w}$ bulb every $22 \mathrm{~m}$. 
Since this midge occurs naturally outdoors in Canada, it may be possible to find them and bring them indoors.

\section{To use Aphidoletes aphidimyza:}

1. Control ants which may protect the aphids.

2. Avoid using residual pesticides in the month prior to introduction.

3. Reduce heavy aphid populations with insecticidal soap, but leave areas with at least 50 aphids/plant $(0.5 \mathrm{~m}$ height $)$ or several leaves on a plant with more than 10 aphids/leaf.

4. Adjust temperatures to favor Aphidoletes $\left(20-27^{\circ} \mathrm{C}\right)$. When diapause is averted by use of night lights, they are effective at temperatures as low as $15^{\circ} \mathrm{C}$.

5. Order Aphidoletes at the rate of $1 \mathrm{pupa} / 10$ aphids or $1 \mathrm{pupa} / \mathrm{m}^{2}$ of planted area.

6. Distribute Aphidoletes by opening pupae containers in shady areas near aphid-infested plants. Keep peat or cotton pupal substrate moist in the containers for at least one week after arrival. Repeat releases in 7-14 days for a total of 3-5 releases.

7. Monitor plants at least once a week by checking all susceptible plants.

A strain of the parasitic fungus Verticillium lecanii, trade name Vertalec, is being marketed in Europe. It requires high humidity and constant warm temperature, which limits its practical use.

Parasites-There are currently no commercially available parasites, however, several native species of tiny wasps parasitize green peach aphid, and often these turn up without introduction, through windows and vents. A sign of their presence is the black or brown mummified shells of their hosts. Aphid mummies still containing parasites (no exit hole visible) can be transferred from one area to another. Sometimes hyperparasites (parasites of the parasites) interfere with this type of control.

Chemical control - Quarantine, check, and treat new plants with insecticidal soap before placing them among established plants. If green peach aphid builds up on blossoms or on new growth, spray the tips with insecticidal soap or Pirimor. If Aphidoletes larvae are present, avoid spraying or hosing down plants since they are readily dislodged and are unable to relocate aphids unless within 6 $\mathrm{cm}$ of them.

\section{CITRUS RED MITE, Panonychus citri}

This mite is a serious citrus pest. In ornamental plantings it will also attack palms, figs, ginger, bananas and various other plants. It does not have the broad host range of the two-spotted spider mite and is far less common, though damaging when present. Similar damage may be caused by several species of false spider mites, Brevipalpus spp., which are almost invisible to the naked eye so often escape blame.

Damage - Injury to leaves results from puncturing of plant cells to feed, which 
causes stippling, pale spots and a silvery appearance. Visible damage is produced by relatively low mite populations.

Occurrence - Citrus red mite can be found on upper and lower leaf surfaces, particularly on new growth.

Appearance and life history - Both adult and immature stages are dark red in color and approximate the two-spotted spider mite in size. The back is covered with long hairs set on small red protuberances visible with a hand lens. Eggs are red, almost spherical and somewhat flattened, with a stalk arising from the top. Development time is approximately 45 days at $10^{\circ} \mathrm{C}, 34$ days at $12^{\circ} \mathrm{C}, 26$ days at $15^{\circ} \mathrm{C}, 20$ days at $18^{\circ} \mathrm{C}, 16$ days at $21^{\circ} \mathrm{C}, 12$ days at $24^{\circ} \mathrm{C}$ and 10 days at $27^{\circ} \mathrm{C}$. Life span, however, decreases with temperature from 48 days at $10^{\circ} \mathrm{C}$ to 5 days at $27^{\circ} \mathrm{C}$, so that optimum temperature for multiplication of this mite is approximately $18^{\circ} \mathrm{C}$, lower than for the two-spotted spider mite. An average of 40 eggs are laid at $25^{\circ} \mathrm{C}$.

Cultural control - Mist plants frequently and provide good growing conditions to reduce susceptibility to damage.

\section{Biological control}

Predators - The predatory mite Phytoseiulus persimilis does feed on this mite and in the process becomes a much darker red than when it feeds on two-spotted spider mite. However, in our experience it does not provide adequate control, particularly on arboreal plant species. The predatory mite Typhlodromus occidentalis provided far better control. Because of its small size it is difficult to see, so declining citrus red mite populations are the best indication that this mite is at work. To use this mite, follow instructions given under two-spotted spider mite.

Chemical control - Quarantine new plants and treat routinely with Vendex or insecticidal soap before placing them among established plants. Spot spray established plants with Vendex if more than $40 \%$ of the upper leaves have citrus red mite or there are on average more than 5 mites/medium-sized leaf with no predatory mites present. If predatory mites are present, treat infested plants with Vendex if damage is occurring or the citrus red mite population is multiplying rapidly.

\section{THRIPS}

Several species of thrips are troublesome in indoor plantings, particularly during the summer months. They often go unnoticed until damage to plants is evident and a search for the culprit is made. Strains of the western flower thrips, Frankliniella occidentalis, have become resistant to many pesticides and are difficult to control.

Damage - Both adults and larvae feed by puncturing plant cells with their mouth parts and sucking up the escaping plant juices. The effect is to cause silvering, flecking and distortion of growing points, fruit and flowers. In addition, the surface may be fouled by small black drops of excretory material.

Occurrence - Leaves, blossoms, buds and leaf sheaths all harbor thrips. 
Appearance and life history - Thrips are tiny, slender insects. Winged adult females lay 25-200 eggs in plant tissue. Nymphs resemble adults except that they are wingless and generally paler in color. They feed for 7-10 days before pupating either in the ground or on the leaf, depending on species. Adults emerge 4-14 days later. Males are uncommon. There are many overlapping generations a year. The banded greenhouse thrips, Hercinothrips femoralis, is a large, slowmoving, dark-brown thrips with yellow legs. It is a foliage feeder and pupates on the leaf. Larvae are glassy white with red eyes. The flower thrips Frankliniella tritici and $F$. occidentalis are tiny, yellowish or yellowish brown species which attack flowers and foliage. They pupate mostly on the ground. Onion thrips, Thrips tabaci, is variable in color, ranging from pale yellow to dark brown. The larva is white or pale yellow and also pupates on the ground. It has several hundred hosts including many vegetables and ornamentals. It feeds on both leaves and flowers. Onion thrips and flower thrips readily enter open windows in the summer months or are brought in on flowering plants.

Cultural control - Mist plants frequently. High humidities are detrimental to many thrips species. Soils high in organic matter seem to favor those thrips which pupate in the soil.

\section{Biological control}

Predators-The predatory mite Amblyseius cucumeris is reared in Europe and Canada for control of flower and onion thrips and is commercially available. The tiny adult is a light brown color and is usually found along leaf veins or inside flowers so is difficult to see unless moving. Total development time from egg to adult is 13 days at $20^{\circ} \mathrm{C}$ and 7 days at $30^{\circ} \mathrm{C}$. Areas of high temperature and low humidity are avoided. Preferred prey are young thrips larvae as older thrips are larger than the predator and defend themselves by flexing their abdomens and striking attacking mites. The number of thrips eaten varies with the different life stages, with the adult female consuming the most prey and eating an average of one thrips per day over its 30 -day life span. Mites of various ages will share prey and feed on thrips that have been killed by other mites. A. cucumeris will feed on alternate food sources such as pollen and spider mites in the absence of thrips. One adult flower thrips can produce approximately 100 offspring over its 60 -day lifespan. This is approximately twice the rate of thrips consumption of $A$. cucumeris and suggests that large numbers of this predator are required to control a thrips infestation. Fortunately this predatory mite can be reared inexpensively in large numbers on a bran mite that substitutes as a host. They are distributed by spreading bran containing predators onto infested plants (e.g. 50 predators per $\mathrm{ml}$ of bran).

The predatory mite Amblyseius mckenziei is also available for thrips control. It was tried in Alberta in one location against onion thrips without noticeable effect.

To use Amblyseius cucumeris:

1. Avoid using residual pesticides in the month prior to introduction.

2. Yellow sticky traps should be used for early warning at rates of one trap for every 50 plants. Use a 10 magnifier to distinguish thrips from other trapped insects. 
3. Introduce predators at the first sign of thrips, or better yet, before thrips are seen on susceptible plants. Remember that the predator can survive on pollen for long periods of time. The best results have been found when predators are released before thrips are seen on plants.

4. Introduce predators at a minimum rate of 30 predators per plant or 50 per plant if thrips are already present. If pollen is present on the plants only one more introduction should be necessary at this rate two weeks later. If pollen is not present, additional releases of at least 10 predators per plant should be made every two weeks.

5. Monitor thrips populations by closely examining leaves with a magnifier or using sticky traps. Traps should be replaced after about one month as the glue dries out and will no longer trap small insects. Releases are no longer necessary if the predator to thrips ratio is 1:1, or thrips are not detected on the leaves or traps.

6. Adult flower thrips prefer newly opened flowers and young leaves while Amblyseius will be found in largest numbers on older flowers and leaves, where they feed on thrips larvae. If it is necessary to reduce high thrips numbers, spot spray the new foliage only with insecticidal soap.

Chemical control - For species which pupate in the soil, a soil surface treatment with diazinon can be integrated with the use of most predators and parasites (not Aphidoletes). Repeat in 2-3 weeks. For thrips which spend their entire life on the leaves, frequent spot treatments with insecticidal soap are recommended. 


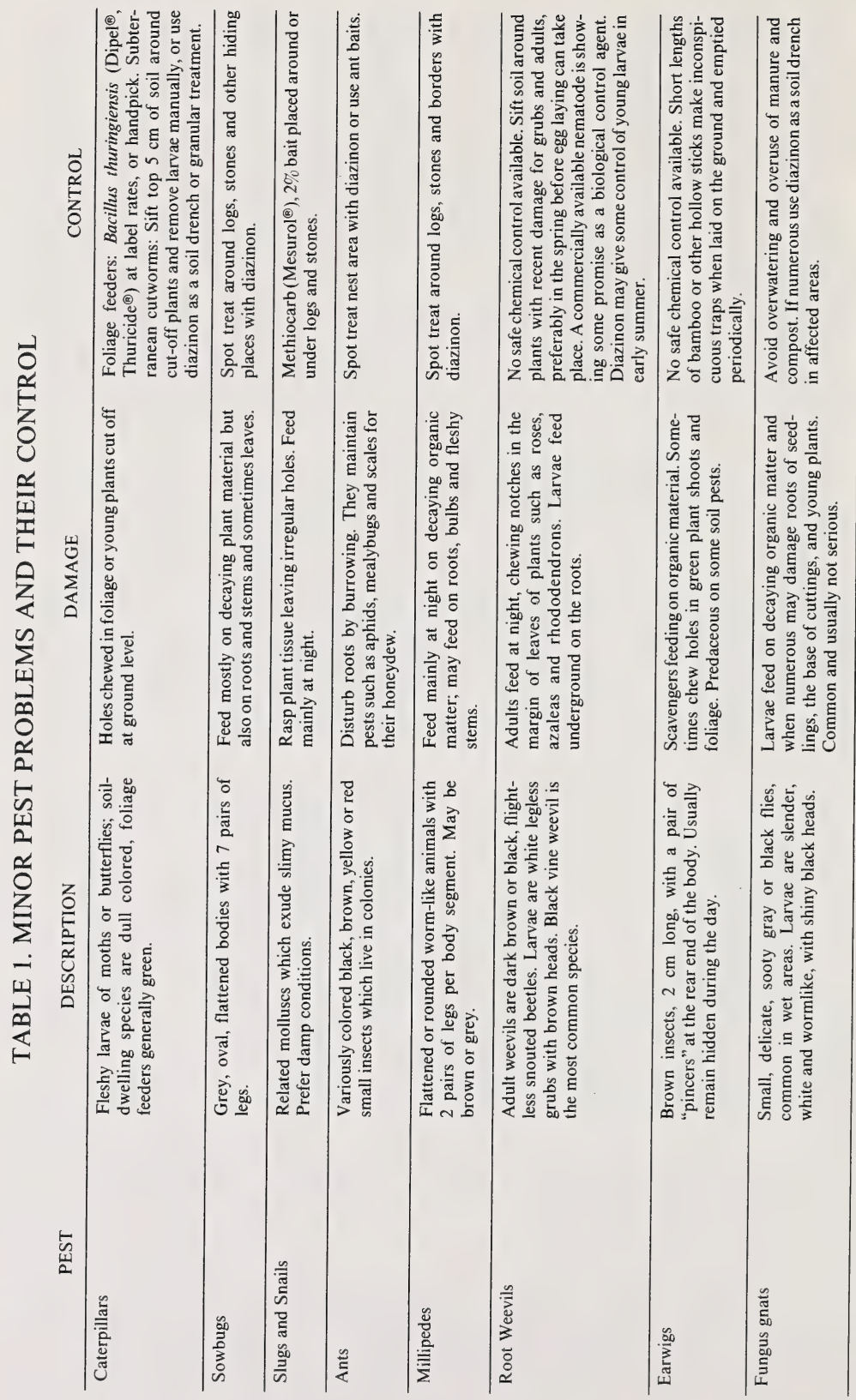




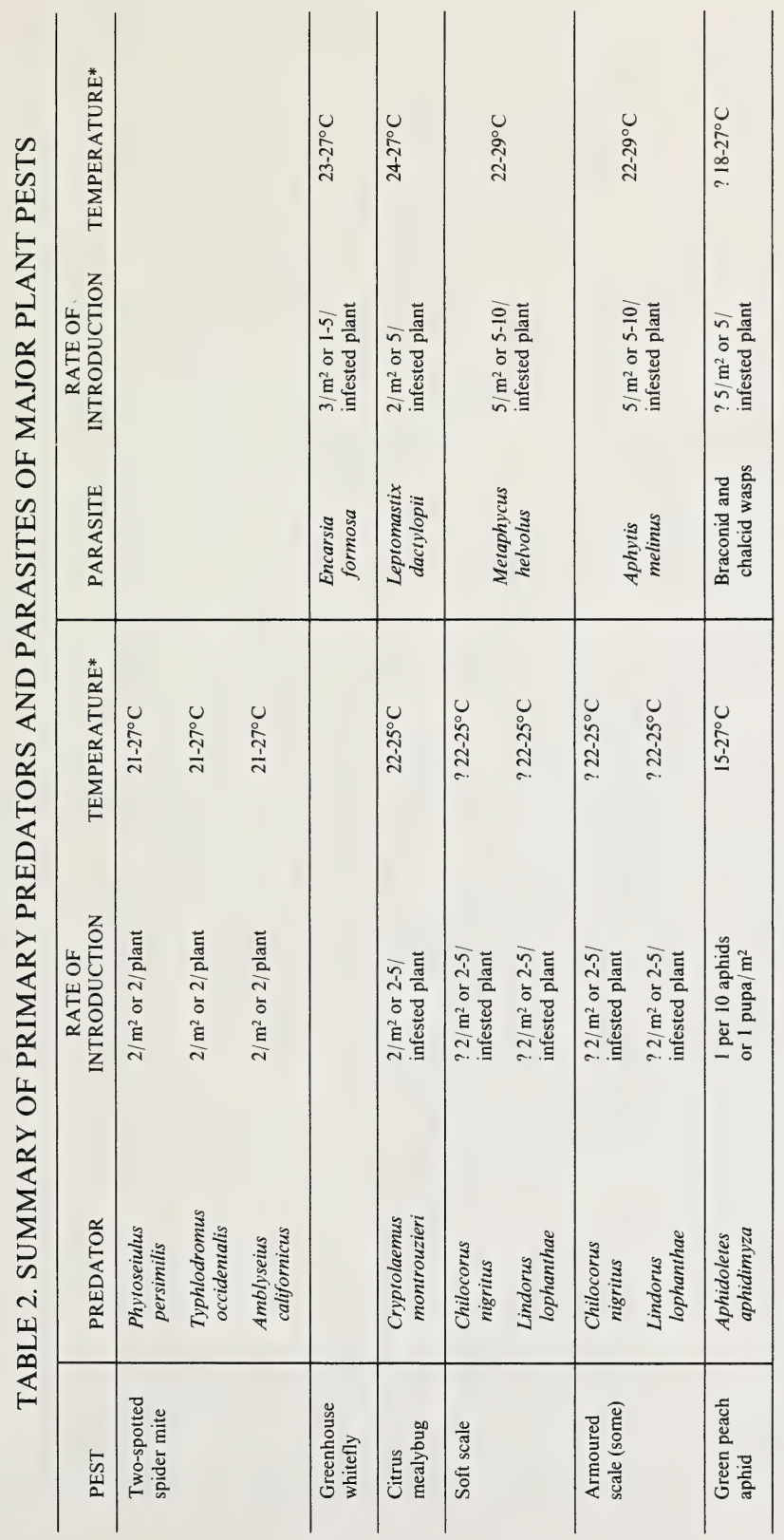




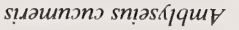

sпјочру snхКчdріаW

рzКичр!чdo sәıวор!чd

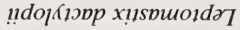

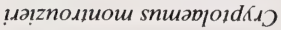

psomiof pis.ipoug

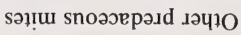

s!p!u!sıad snpп!วso1кYd

ค 8 |

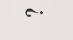

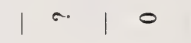

8
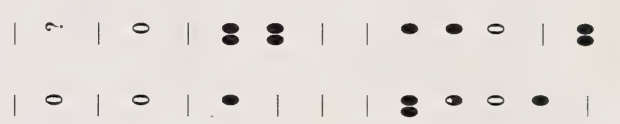


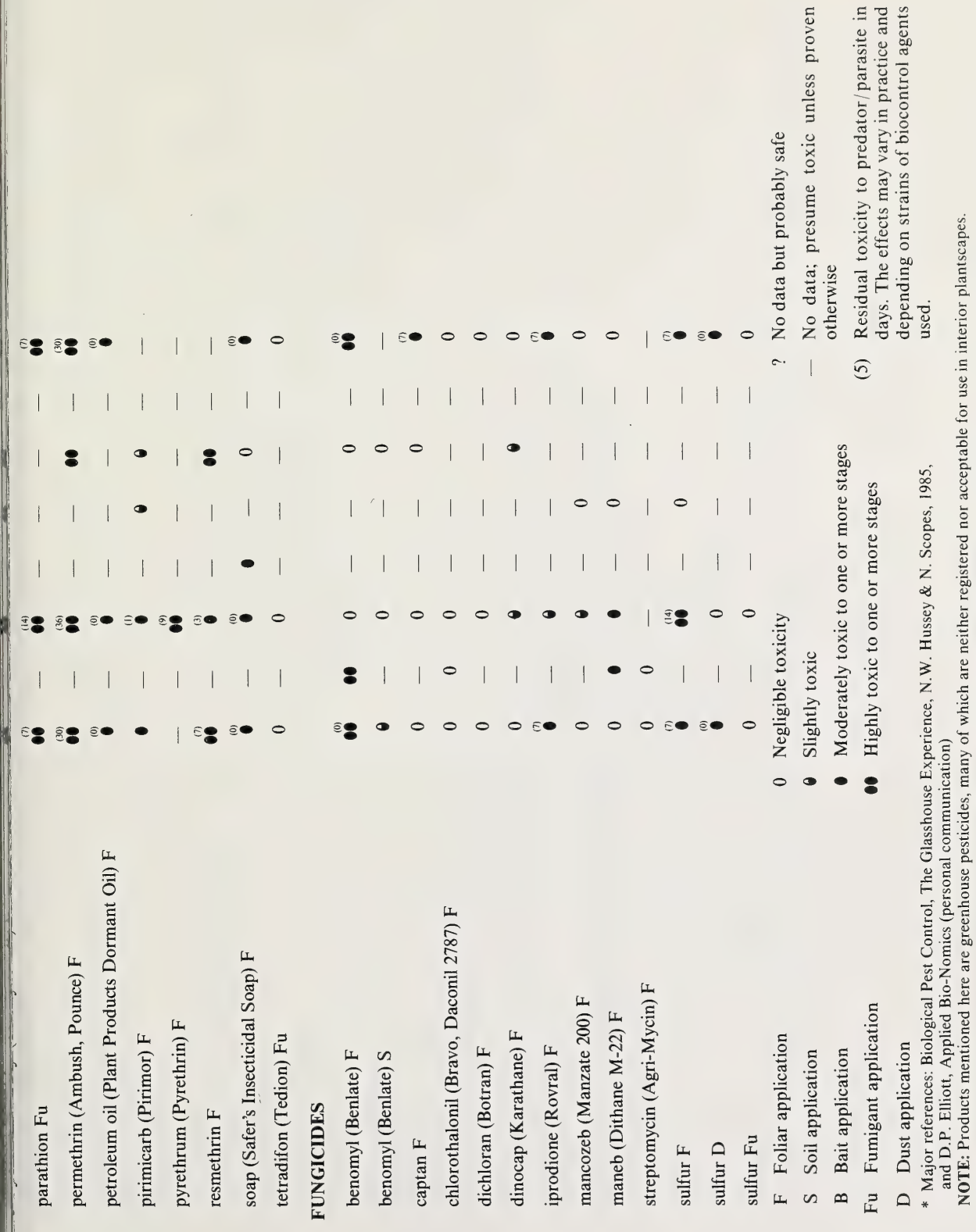




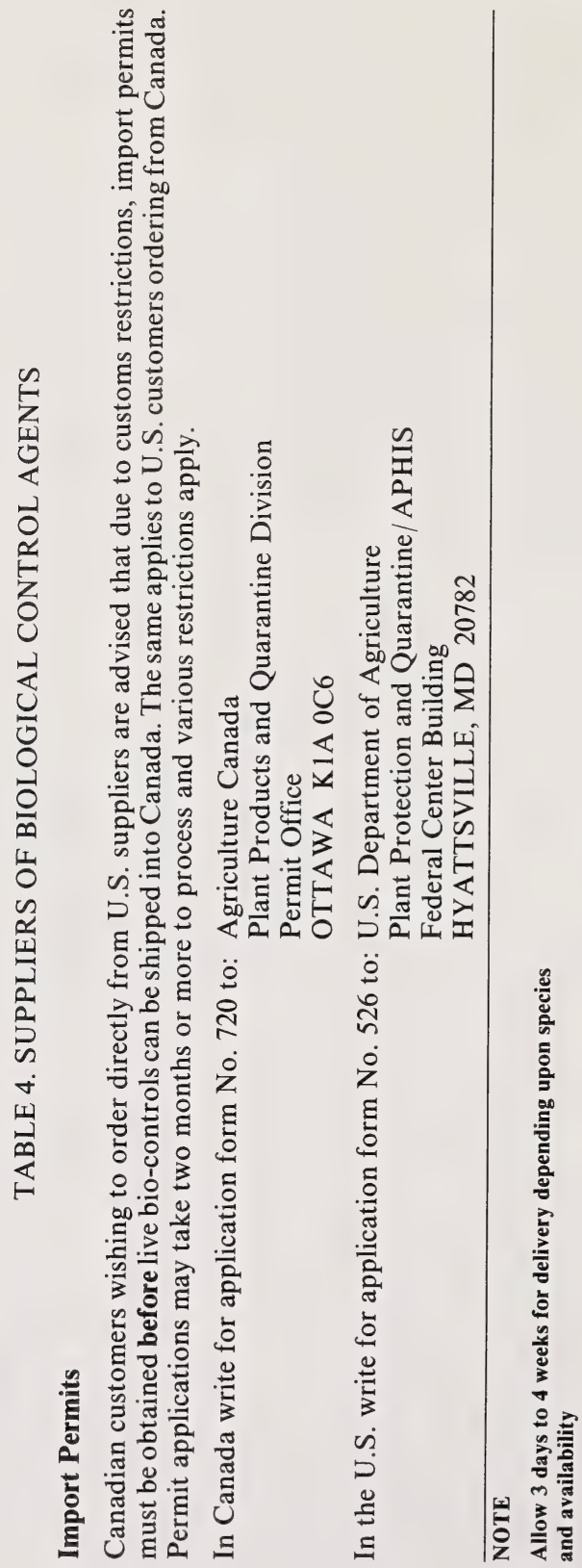

s!p!บ10!ฺy s!1!pqрy.10.1ว1วH

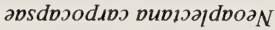

apyıuрydol snıopú?

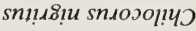

$\circ$

$\circ$

!ว!zuауош sn!วsкlquV

s!ıนunons sn!วs $/ q u V$

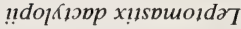

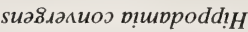

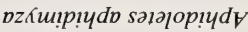

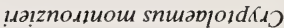

sпu!|วu s!ฺरчdV

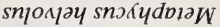

psou1 of pisıpsug

snग!u1of!!po sn!asরiquV

s!̣рıирр!วоо sпшохроччd ${ }_{L}$

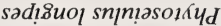

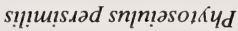

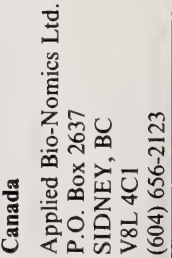




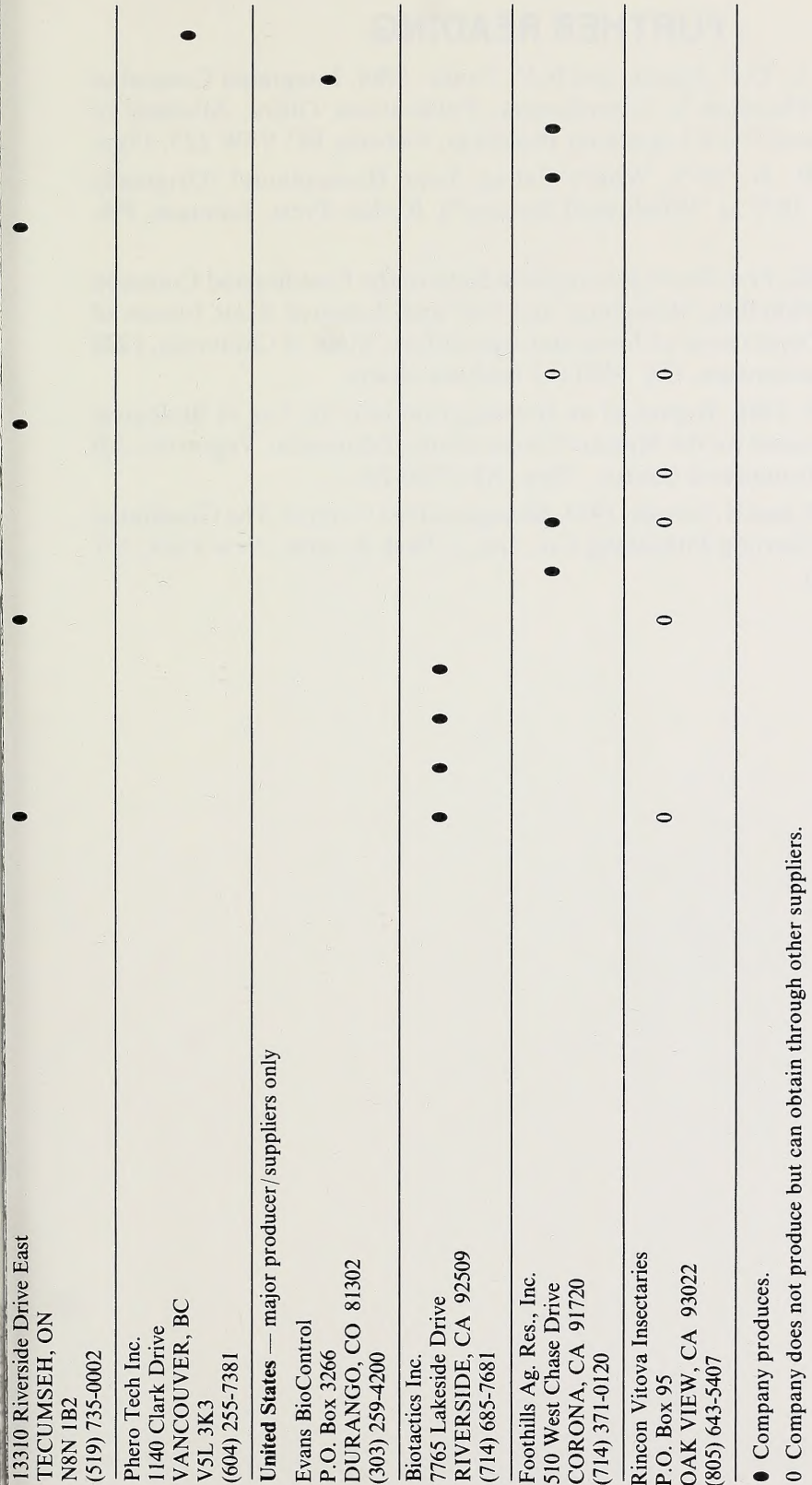




\section{FURTHER READING}

1. Costello, R.A., D.P. Elliott, and N.V. Tonks. 1984. Integrated Control of Mites and Whiteflies in Greenhouses. Publications Office, Ministry of Agriculture and Food, Legislative Buildings, Victoria, BC V8W 2Z7. 17pp.

2. Jordan, W.H. Jr. 1979. What's Eating Your Houseplants? (Originally published in 1977 as "Windowsill Ecology"). Rodale Press, Emmaus, PA. 229pp.

3. Gill, R.J. 1982. Five Photo Recognition Keys to the Families and Common Species of Whiteflies, Mealybugs and Soft and Armored Scale Insects of California. Department of Food and Agriculture, State of California, 1220 N. Street, Sacramento, CA 95814. 5 fold-out charts.

4. Steiner, M.Y. 1986. Report of an Investigation into the Use of Biological Pest Management for the Muttart Conservatory, Edmonton. Vegreville, AB Alberta Environmental Centre. 70pp. AECV86-R6.

5. Hussey, N.W. and N. Scopes. 1985. Biological Pest Control, The Glasshouse Experience. Sterling Publishing Co., Inc., 2 Park Avenue, New York, NY 10016. 240pp. 

